\title{
Universul minune al microbiomului
}

\author{
Adrian Bălănean
}

Scientific Manager Nestle Infant Nutrition Romania

Dragi cititori,

Flora intestinală, cunoscută şi sub denumirea de microbiom, joacă un rol important în dezvoltarea şi creşterea sănătoasă în copilărie. Compoziţia deosebită a laptelui matern îi oferă nou-născutului o nutriţie optimă şi sprijină microbiomul. Acesta conţine o mare abundenţă de substanţe cu efect pozitiv.

In prezent, interesul s-a îndreptat considerabil către aşa numitele oligozaharide din laptele uman (HMO), care constituie un element esential din structura laptelui matern.

Cercetătorii cunoşteau deja importanţa acestor componente, însă doar recent a fost posibilă imbogăţirea formulelor de lapte praf pentru sugari cu HMO selectate şi deosebit de importante. Aceste HMO sunt aceleaşi cu cele regăsite în laptele matern. Ele au fost evaluate pozitiv atât în Europa, cât şi in SUA (EFSA a acordat statutul "Novel Food", FDA a acordat statutul GRAS). Primele rezultate ale acestor studii arată foarte promiţător.

În paginile următoare, puteţi afla mai multe despre acest subiect interesant.

„Un pas înainte în cercetare la fel de important ca aselenizarea!“ Aşa descriu alţi experţi entuziaşti foarte serioşi şi obiectivi cel mai recent progres în ştiinţa alimentară. Şi nu fără motive întemeiate, deoarece într-un timp foarte scurt s-au creat condiţiile care deschid o nouă eră în nutriţia sugarilor. Secretul se numeşte HMO.

$\mathrm{Cu}$ zece ani în urmă, microbiomul - cunoscut pe atunci sub numele de floră intestinală - era un subiect de studiu înţeles de doar câţiva specialişti în microbiologie. Însă, între timp, a devenit un domeniu de studiu expansiv. Este din ce în ce mai evident că acestui domeniu extraordinar de complex i se poate atribui un rol decisiv în dezvoltare, stare de bine şi sănătate pe termen lung. Se pare că influenţează chiar şi sentimentele şi comportamentul. Microbiomul este recunoscut tot mai mult ca organ de sine stătător - un organ foarte deosebit deoarece se schimbă pe parcursul vieţii şi îl putem modifica chiar şi noi!

\section{Milioane de prieteni buni}

Chiar şi numai dimensiunile sunt impresionante! Deoarece microbiomul cuprinde bacterii, fungi, virusuri şi metaboliţi produşi de acestea în organism. Microbiomul intestinal, adică totalitatea microbilor din intestinul uman, atinge cifre incredibile:

\section{Flora intestinală a adulților:}

- 100 de trilioane $\left(10^{14}\right)$ de bacterii

- De 10 ori mai multe decât toate celulele din corp

- Aprox. 36.000 de specii diferite

- Aprox. 1-2 kg de biomasă

- Microbiomul intestinal cuprinde aproximativ 3,3 milioane de gene

- Aproximativ de 150 de ori mai mult decât genomul uman

Evident, microbiomul nu există într-o formă aleatorie, ci există combinaţii preferate de bacterii, aşa numitele enterotipuri, aparent asociate cu obiceiurile alimentare.

\section{Este intestinul un al doilea creier}

Relaţia cu starea de sănătate este deosebit de interesantă. Deoarece un număr tot mai mare de afecţiuni care nu au cauze intestinale par a fi influenţate considerabil de starea microbiomului, inclusiv afecţiunile respiratorii, obezitatea, diabetul zaharat de tip 2, alergiile şi astmul. Există chiar dovezi care arată că autismul, depresia sau durerea cronică sunt afecţiuni de pe axa creier-intestin. Având în vedere ultimele descoperiri, ghidurile actuale Roma IV privind afecţiunile gastro-intestinale funcţionale (FGID) recomandă ca pe viitor să se utilizeze sintagma „Tulburare a interacţiunii intestin-creier" (DGBI).

Există voci care afirmă chiar că intestinul este un ,,al doilea creier“, care ne controlează gândurile 
şi (sub)conştientul în mod similar cu creierul. Aşadar, concluzia evidentă este că un microbiom intestinal echilibrat are o influenţă semnificativă asupra sănătăţii şi, prin urmare, nutriţia este un factor important (Fig. 1).

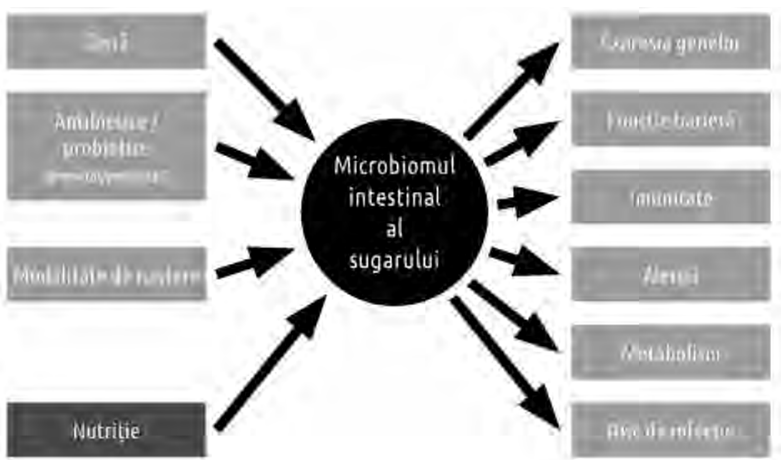

FIGURA 1. Microbiomul intestinal - centru de control Modificat pe baza Houghteling et al. J Pediatr Gastroenterol Nutr. 2015;60(3):294-307

\section{Laptele matern este cel mai bun}

În acest context, compoziţia laptelui matern are un rol decisiv. Deoarece, astfel, organismul sugarilor primeşte cele mai importante componente ale unei flore intestinale sănătoase. Laptele matern oferă cele mai importante bacterii ,probiotice“ bifidus şi lactobacillus al căror efect pozitiv este cunoscut de mult timp.

Din $800 \mathrm{ml}$ de lapte matern consumat zilnic, un sugar ingerează aproximativ 1 milion de bacterii care conţin bifidobacterii şi lactobacillus. La efectul bifidogen al laptelui matern contribuie numeroşi factori.

\section{HMO cu funcţii multiple}

Dintre numeroasele componente cu efect de protecţie, oligozaharidele din laptele uman (HMO) joacă un rol decisiv. HMO sunt prezente exclusiv în laptele matern. După lactoza şi grăsimile din lapte uman, oligozaharidele din laptele uman reprezintă al treilea cel mai mare grup de componente din laptele matern (Fig. 2).

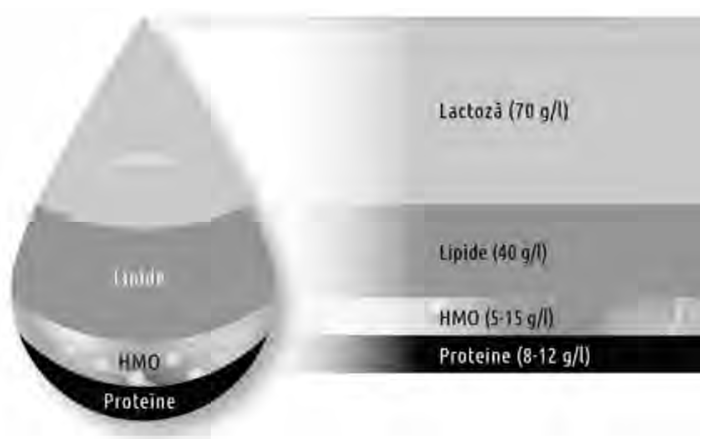

FIGURA 2. A treia cea mai mare componentă solidă din laptele matern

Jantscher-Krenn et al. Minerva Pediatr 2012a;64:83-89
HMO sunt prezente într-o varietate amplă de structuri şi cantităţi. Compoziţia individuală depinde de diferiţi factori. Compusul cu cea mai mare cantitate este, in acest caz, 2-fucozillactoza (2FL), care constituie in majoritatea cazurilor aproximativ o treime din conţinutul total de HMO (Fig. 3). $2 F L$ are $u n$ efect deosebit de pozitiv asupra microbiomului copiilor alăptați.

De peste o sută de ani, oamenii de ştiinţă şi pediatrii sunt fascinaţi de aceste componente importante din laptele matern, atât datorită diversităţii acestora cât şi datorită beneficiului pentru organismul sugarilor. Progresele tehnologice mai recente în ce priveşte fabricarea de HMO individuale au făcut posibilă studierea acestora şi în studii clinice randomizate şi controlate cu placebo.

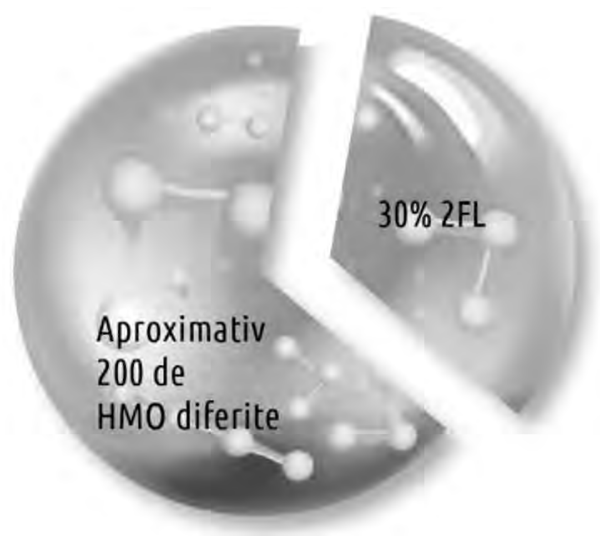

FIGURA 3. Cel mai mare procent de HMO:2FL Kobata A, Proc Jpn Acad Ser B Phys Biol Sci, 2010

\section{Zaharuri complexe cu efect}

Oligozaharidele din laptele uman (HMO) sunt o componentă nutriţională esenţială pentru copiii alăptaţi. Absența acestor componente este cea mai importantă diferenţă între laptele matern şi laptele praf pentru sugari.

Oligozaharidele din laptele uman au o structură specială, sunt disponibile într-o varietate amplă de forme şi sunt a treia cea mai mare componentă a laptelui matern. HMO au o structură relativ simplă însă toate au la bază cinci substanţe esenţiale. Aproape toate HMO au la bază lactoza modificată în glanda mamară prin adăugarea de monozaharide precum fucoza, N-acetilglucozamina şi/sau acidul sialic. Astfel, se formează structuri complexe cu legături foarte specifice, care stau la baza naturii multifuncţionale a HMO (Fig. 4). 


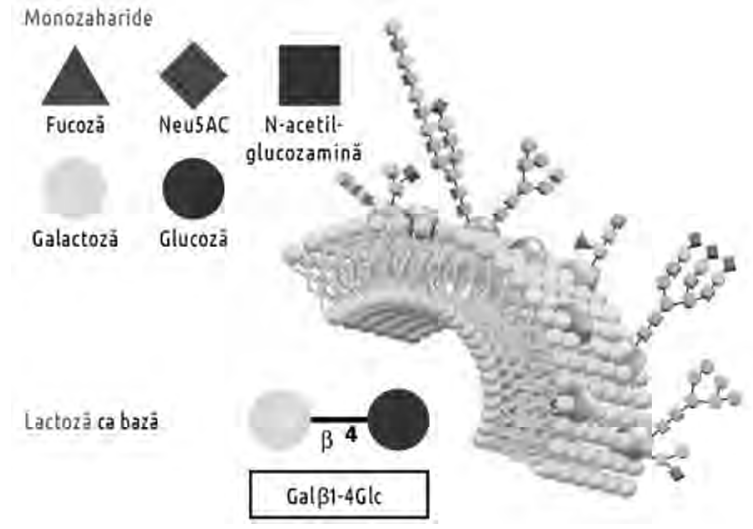

FIGURA 4. Aceleaşi blocuri structurale, legături diferite Adaptare după: Rohrer J: HPAE-PAD Peak Area Response of Glycoprotein Oligosaccharides, Thermo Fisher Scientific Tech Note 133, 2016

Concentratia totală de HMO în laptele matern matur este intre 10 şi $15 \mathrm{~g} / \mathrm{l}$-aceasta poate fi mai inaltă în colostru. La majoritatea mamelor, $2 F L$ este prezentă în cea mai mare cantitate, aproximativ $30 \%$.

\section{Efect bifidogen}

Dacă se analizează compoziţia microbiotică a intestinului la sugarii alăptaţi, se observă în mod normal o prevalenţă distinctă a bifidobacteriilor şi un procent mai mic de bacterii cu potenţial patogen. Prin stimularea bifidobacteriilor folosind HMO diferite, se poate preveni introducerea substanţelor patogene, după cum György a reuşit să stabilească deja în 1955. Datele recente conduc la concluzia că, aparent, anumite sub-tulpini bacteriene au capacitatea de a utiliza HMO şi/sau diferite forme ale HMO (Fig. 5).

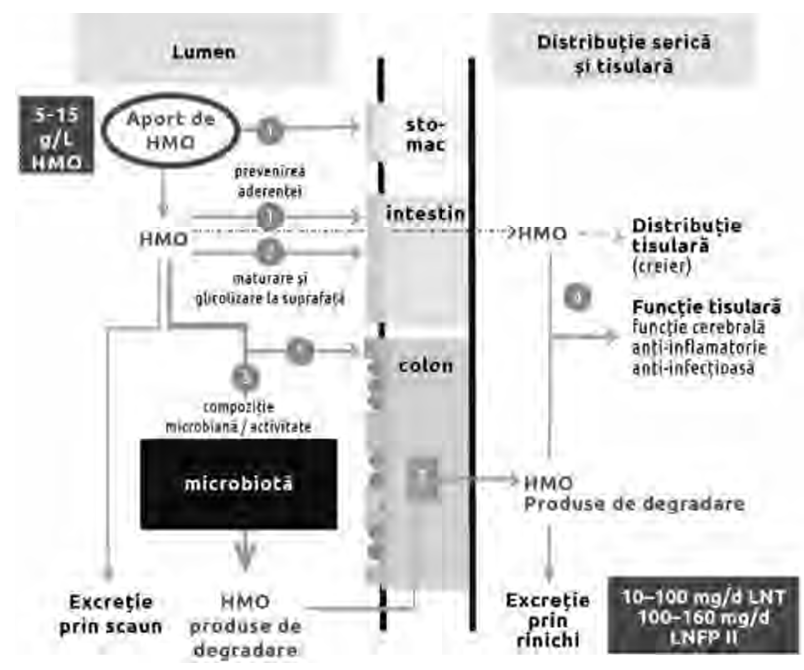

FIGURA 5. Aport, metabolism şi funcții potențiale

Kunz C, Das Nest 40, 2016
Este, astfel, tot mai clar că HMO sunt factori multifuncţionali extraordinari pentru o dezvoltare sănătoasă (Fig. 6).

- HMO facilitează dezvoltarea bifidobacteriilor specifice în intestinul sugarilor.

- HMO sunt „momeala“ pentru agenţii patogeni. Aceştia aderă la HMO şi sunt excretaţi în scaun împreună cu acestea.

- HMO consolidează funcţia barieră a intestinului, previn aderenţa patogenilor potenţiali la celulele intestinale, ,reprogramându-le“.

- HMO au un efect de reglare imunitară, acestea contribuie la dezvoltarea răspunsurilor imunitare Th1/Th2 echilibrate.

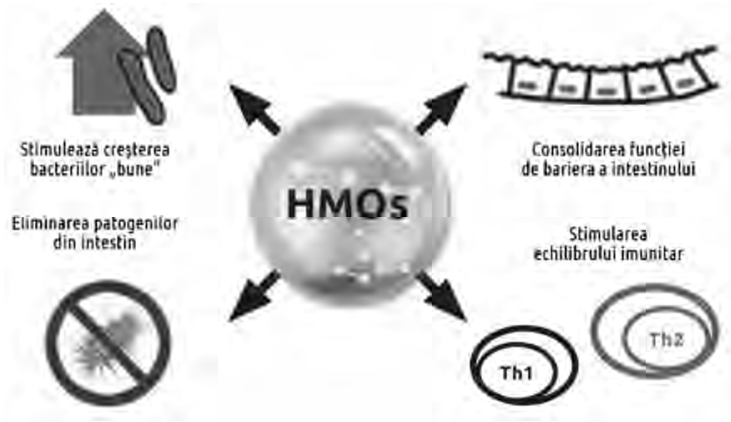

FIGURA 6. Mecanisme importante ale HMO Jantscher-Krenn, Bode: Minerva Paediatr. 2012; Bode L, Glycobiology, 2012; Smilowitz JT, Lebrilla CB, Mills DA et al. Annu Rev Nutr. 2014

\section{HMO: Mai mult decât doar prebiotice}

Mai recent, a devenit o practică normală să se adauge anumiţi carbohidrați precum galacto(GOS) şi fructo-oligozaharide (FOS) în formulele de lapte praf pentru sugari, cu promisiunea că vor induce un efect pozitiv asupra dezvoltării microbiomului la sugar. Însă acestea nu sunt la fel cu oligozaharidele umane (HMO). Mecanismul de acţiune al celor din urmă are o acţiune mult mai amplă decât GOS/FOS.

O diferenţă semnificativă constă în faptul că FOS nu sunt prezente deloc în laptele matern, iar GOS sunt prezente doar în cantităţi extrem de mici. Deşi aceste prebiotice stimulează şi colonizarea bacteriilor bifidogene în intestinul nou-născuţilor şi al copiilor de vârste mici, efectul acestora este, per total, considerabil mai limitat decât în cazul HMO. Acest aspect se datorează diferenţelor structurale:

HMO au structuri şi componente mai complexe, care nu există în FOS/ GOS.

- FOS au două componente şi un tip de legătură la fel de simplă ca piesele Lego

- GOS au, de asemenea, două componente, însă forme de legătură diferite 
- HMO au cel puţin trei componente şi o multitudine de legături diferite

Numeroase funcţii ale HMO depind de structură. Din acest motiv, FOS/GOS nu pot avea acelaşi mecanism de acţiune ca HMO.

\section{Prebiotice}

- Au o acţiune mai puţin specifică asupra microbiomului intestinal

- Nu pot „ademeni““ şi elimina patogenii

- Nu pot consolida direct funcţia de barieră intestinală

- Nu au efect direct asupra echilibrului imunitar

In primul rând, HMO oferă caracteristicile pozitive ale laptelui matern şi au un efect protector complex asupra florei intestinale la sugari.

\section{Pe urma oligozaharidelor}

Prima descriere a microorganismelor precum lactobacillus şi bifidobacteriile datează încă din 1900 . Chiar şi la acel moment, au existat primele indicații că diferențele dintre compoziţia diferită a scaunelor sugarilor alăptaţi şi ale celor hrăniţi cu lapte praf se asocieaza cu diferențele dintre carbohidraţii. Apoi, la începutul anilor 1930, s-au caracterizat primele oligozaharide individuale din laptele matern.

În anii 1950 s-a făcut un pas uriaş în cercetarea HMO, când pediatrul Paul György şi chimistul Richard Kuhn au reuşit să demonstreze că factorul de creştere pentru Lactobacillus bifidus (clasificat ulterior ca Bifidobacterium bifidus) există în laptele matern sub formă de oligozaharide.

În anii următori, s-au descoperit şi clasificat mai mult de douăsprezece HMO. De la începutul mileniului, s-au făcut progrese impresionante în dezvoltarea metodelor de analiză detaliată a structurii, chiar şi pentru cantităţile extrem de mici de lapte. În acelaşi timp, a fost posibilă producerea unor cantităţi mai mari de $\mathrm{HMO}$ individuale prin metode chimice şi biotehnologice.

După investigarea iniţială a efectului prebiotic, s-a pus din ce în ce mai mult accentul pe alte avantaje pe care le au HMO asupra sănătăţii. La acest moment, s-a discutat modul şi ce oligozaharide pot fi adăugate în formulele de lapte pentru a obţine efecte pozitive similare cu cele ale HMO din laptele matern.

În $2012 \mathrm{~s}-\mathrm{a}$ derulat primul studiu clinic cu suplimentarea cu HMO a alimentaţiei, după ce numeroase studii in vitro şi la animale au avut rezultate foarte promiţătoare.
Abrevieri importante
$\mathrm{HMO}=$ Oligozaharide din laptele uman
2FL = 2-Fucozillactoză
LNT $=$ Lacto-N-tetraoză
GOS $=$ Galacto-oligozaharide
FOS $=$ Fructozo-oligozaharide
FGID = functional gastro-intestinal disorders
DGBI $=$ disorders of Gut-Brain Interaction
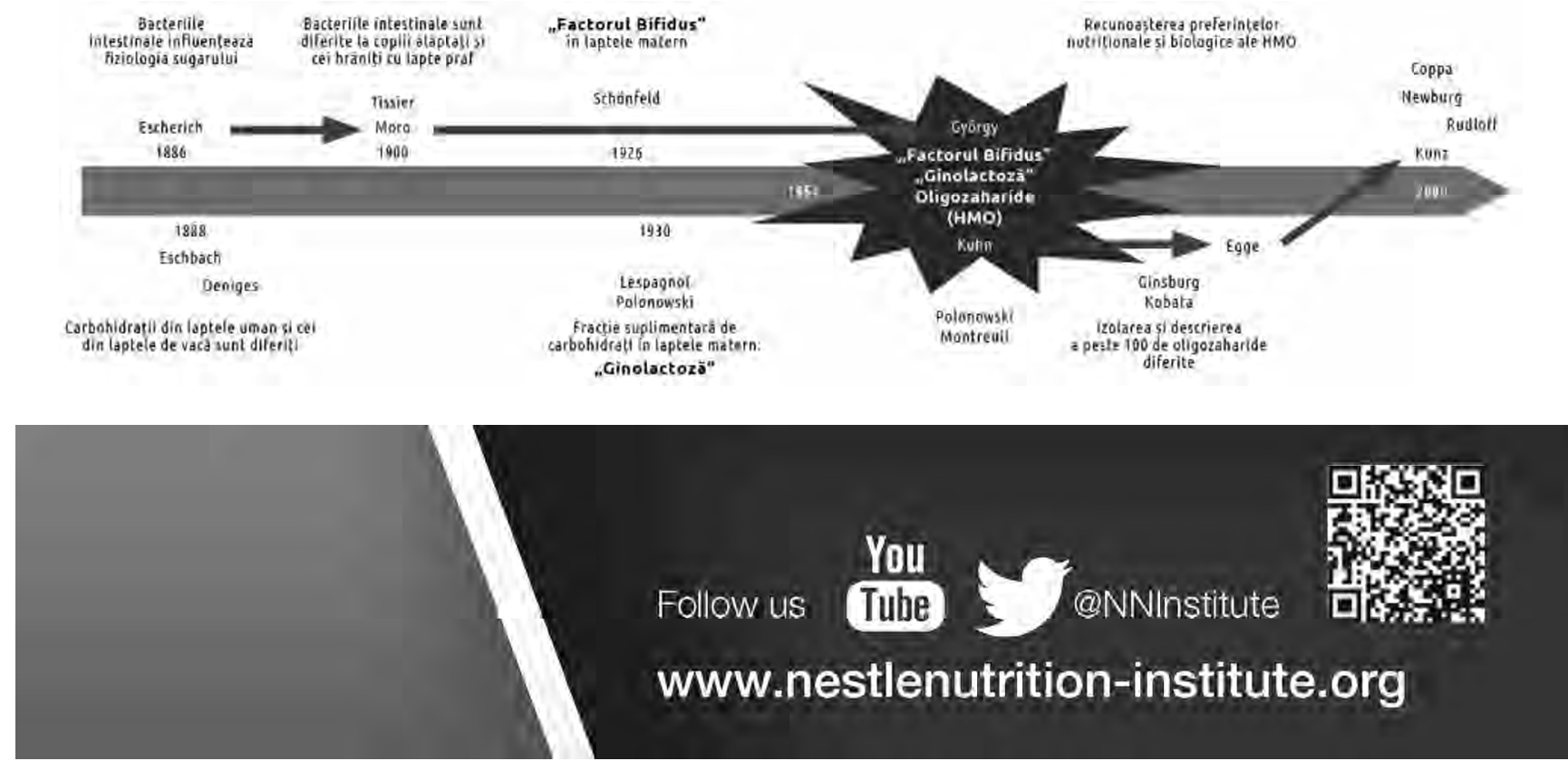